\title{
PENGARUH KEPEMIMPINAN TRANSFORMASIONAL DAN MOTIVASI BERPRESTASI TERHADAP KOMITMEN ORGANISASIONAL GURU DI SMP NEGERI 1 SELOPURO KABUPATEN BLITAR
}

\author{
Cicik Susana \\ Eka Askafi \\ Aris Syahidin \\ Program Studi Magiter Manajemen Universitas Islam Kadiri \\ e-mail.ciciksusana@gmail.com
}

\begin{abstract}
This research is to know the influence of transformational leadership and achievement motivation toward organizational commitment of teacher in SMPN 1 Selopuro Blitar Regency. The research was conducted by questionnaire survey method at the teacher at SMPN 1 Selopuro Blitar Regency. Data collection was done by distributing questionnaires to respondents. Questionnaires were distributed to 43 teachers at SMPN 1 Selopuro Blitar. The analytical tool used is Multiple Linear Regression using 16.00 for windows application. The results showed that: 1) There was no positive and significant influence of transformational leadership on organizational commitment of teachers in SMPN 1 Selopuro Blitar Regency; 2) There is a positive and significant influence of achievement motivation on organizational commitment of teachers in SMPN1 Selopuro Blitar Regency; and 3) There is a positive and significant influence of transformational leadership and achievement motivation simultaneously to the organizational commitment of teachers in SMPN1 Selopuro Blitar Regency.
\end{abstract}

Key Words: Transformational Leadership, Achievement Motivation, Organizational Commitment.

\section{ABSTRAK}

Penelitian ini untuk mengetahui pengaruh kepemimpinan transformasional dan motivasi berprestasi terhadap komitmen organisasional guru di SMPN 1 Selopuro Kabupaten Blitar. Penelitian dilakukan dengan metode survei angket pada guru di SMPN 1 Selopuro Kabupaten Blitar. Pengumpulan data dilakukan dengan cara membagikan angket pada responden. Angket dibagikan kepada 43 responden guru di SMP Negeri 1 Selopuro Kabupaten Blitar. Alat analisis yang digunakan adalah Regresi Linier Berganda dengan menggunakan aplikasi 16,00 for windows. Hasil penelitian menunjukkan bahwa: 1) Tidak terdapat pengaruh positif dan signifikan kepemimpinan transformasional terhadap komitmen organisasional guru di SMPN 1 Selopuro Kabupaten Blitar; 2) Terdapat pengaruh positif dan signifikan motivasi berprestasi terhadap komitmen organisasional guru di SMP Negeri 1 Selopuro Kabupaten Blitar; dan 3) Terdapat pengaruh positif dan signifikan kepemimpinantransformasional 
danmotivasi berprestasi secara simultan terhadap komitmen organisasional guru di SMPN 1 Selopuro Kabupaten Blitar.

\section{Kata Kunci: Kepemimpinan Transformasional, Motivasi Berprestasi,Komitmen Organisasional.}

\section{PENDAHULUAN}

Komitmen organisasi merupakan konsep penting dalam manajemen dan telah dipelajari secara luas oleh para peneliti organisasi, terutama dalam psikologi organisasi dan perilaku organisasi (Meyer et al dalam Laka, 2013).Komitmen organisasi sebagai keadaan psikologis yang mencirikan hubungan karyawan dengan organisasi dan memiliki implikasi bagi keputusan untuk melanjutkan keanggotaan dalam organisasi. Komitmen organisasi mengandung pengertian sebagai sesuatu hal yang lebih dari sekedar kesetiaan yang pasif terhadap perusahaan, dengan kata lain komitmen organisasi menyiratkan hubungan karyawan dengan organisasi atau perusahaan secara aktif.

Komitmen organanisasi dipengaruhi oleh bebarapa faktor. Menurut Morrow dalam Laka (2013) faktor demografi seperti umur, jenis kelamin, status perkawinan, tingkat pendidikan dan pengalaman kerja mempengaruhi komitmen yang dimiliki oleh seorang karyawan. Banyak penelitian telah dilakukan untuk mengetahui faktor-faktor yang menyebabkan tingkat komitmen seorang karyawan terhadap organisasinya.Setiap penelitian disesuaikan dengan disiplin ilmu dari setiap ahli (Putranta, 2008). Dalam penelitian ini akan melihat bagaimana komitmen dipengaruhi oleh gaya kepemimpinan seseorang dan bagaimana kedua faktor tersebut bersama-sama mempengaruhi kinerja karyawan.

Organisasi pendidikan tidak terlepas dalam kegiatan dan budaya organisasi.Guna untuk, mewujudkan tujuan oraganisasi mencerdaskan anak bangsa.Demikian halnya, SMPN 1 Selopuro untuk menciptakan tujuan irganisasi sebagai pelayanan publik, maka perlu sekali konmitmen organisasi semua pihak. Keterlibatan pihak inilah yang perlu dan penting untuk mencapai tujuan itu.Eksistensi SMPN 1 yang berupasti dan berakreditasi A perlu adanya peningkatan serta untuk mempertahan mutu pendidikannya sebagai out put dari pendidikan ini, sekaligus citra positif dalam masyarakat.

Sikap yang ditunjukan dapat melibatkan fisik, psikis, atau juga kognitif. Karyawan yang merasa terikat atau engaged akan mampu memberikan keseluruhan dirinya dalam usaha pencapaian tujuan, visi dan misi perusahaan (Kahn, 1990). Dalam penelitiannya, Robert (2006) dalam Laka (2013) menemukan adanya relasi yang positif antara employee engagement dan komitmen organisasi.

Karyawan dengan tingkat engagement yang tinggi mendatangkan tingkat komitmen yang tinggi pada organanisasi dengan demikian mendatangkan keunggulan kompetitif bagi perusahaan, kinerja yang tinggi serta rendah turn over. Kogie (2008) dalam Laka (2013) menemukan bahwa work engagement mempengaruhi tingkat komitmen seorang pekerja pada perusahaannya. Karyawan yang engaged memiliki komitmen pada organisasinya dengan memberikan kinerja yang baik serta mendapatkan kesejahteraan dalam kehidupannya. Cho, Heater dan 
Carol (2006), dalam penelitian yang dilakukan menyimpulkan bahwa work engagement memiliki pengaruh yang positif terhadap komitmen organisasi sebagaimana yang disimpulkan pula oleh Field dan Johana (2011).Work engagement yang tinggi akan berpengaruh positf terhadap komitmen bekerja karyawan. Hasil positif tersebut secara tidak langsung akan menggambarkan bagaimana kepuasan seorang karyawan bekerja di dalam sebuah organisasi.

Organisasi dapat dikatakan sebagai alat untuk mencapai tujuan, oleh karna itu organisasi dapat dikatakan wadah kegiatan dari pada orang-orang yang bekerjasama dalam usahanya untuk mencapai tujuan.Di kegiatan itu orang-orang harus jelas tugas, wewenang dan tanggung jawabnya, hubungan dan tata kerjanya.Pengertian yang demikian disebut organisasi yang "statis", karena sekedar hanya melihat dari strukturnya.Di samping itu terdapat pengertian organisasi yang bersifat "Dinamis".Pengertian ini organisasi dilihat dari pada sudut dinamikanya, aktivitas atau tindakan dari pada tata hubungan yang terjadi di dalam organisasi itu, baik yang bersifat formal maupun informal.

Pemimpin yang handal bukan saja harus piawai dalam menyusun strategi, tetapi juga dapat menjalankan strategi dengan efektif. Karena pemimpinlah yang akan melahirkan strategi dan sekaligus berupaya keras agar dapat mewujudkan strategi itu. Seorang pemimpin yang dinilai berhasil adalah pemimpin yang tanggap akan keadaan, situasi, hingga adanya perubahan terhadap organisasi yang dipimpinnya sehingga dapat memaksimalkan segala sumber daya yang terdapat di dalamnya dan menghasilkan kinerja organisasi yang baik. Sampai aat ini banyak sekali konsep tentang kepimimpinan yang diungkapkan oleh beberapa ahli.

Kepemimpinan dideskripsikan dalam beberapa istilah berdasarkan dengan ciri dan tindakan yang dilakukan mulai dari kepemimpinan kharismatik, kepimimpinan transaksional, hingga istilah terkini yang banyak dikemukakan adalah kepimimpinan transformasional, yang kini banyak Model kepemimpinan transformasional merupakan model yang relatif baru dalam studi-studi kepemimpinan. Model ini dianggap sebagai model yang terbaik dalam menjelaskan karakteristik pemimpin. Konsep kepemimpinan transformasional mengintegrasikan ide-ide yang dikembangkan dalam pendekatan watak, gaya dan kontingensi. Esensi kepemimpinan transformasional adalah sharing of power.Dalam konsep ini, seorang pemimpin transformasional melibatkan bawahan secara bersama-sama untuk melakukan perubahan, atau sering disebut wujud pemberdayaan.Melalui kepemimpinan transformasional ada suatu keterikatan yang positif antara atasan dan bawahan.

Pemimpin transformasional harus mampu mendefinisikan, mengkomunikasikan dan mengartikulasikan visi organisasi, dan bawahan harus menerima dan mengakui kredibilitas pemimpinnya. Pemimpin transformasional juga harus mempunyai kemampuan untuk menyamakan visi masa depan dengan bawahannya, serta mempertinggi kebutuhan bawahan pada tingkat yang lebih tinggi dari pada apa yang mereka butuhkan. Keberadaan para pemimpin transformasional mempunyai efek transformasi baik pada tingkat organisasi maupun pada tingkat individu. dimensi dari gaya kepemimpinan transformasional, Inspirational leadership merupakan gaya kepemimpinan yang dipilih oleh responden untuk keefektifan seorang pemimpin, sebaliknya gaya kepemimpinan 
transaksional seperti laissez-faire merupakan kepemimpinan yang dihindari oleh pemipinan SMP Negeri Selopuro Kabupaten Blitar.

Berawal fenomena tersebut penulis akan melihat pada sebuah pendidikan yang ada SMP Negeri 1 Seloporo Kabupaten Blitar. Fakus penelitian terfakus pada manajemen yang ada pada intansi pendidikan yakni SMP Negeri 1 Seloporo Kabupaten Blitar.Sekolahan ini merupakan sekolahan Negeri Umum tingkat pertama yang ada di Kecamatan Selopuro Kabupaten Blitar. Selain itu SMP Negeri 1 Seloporo Kabupaten Blitar mendapatkan akreditasi A hal ini salah satu latar belakang penelitian ini.

Dengan uraian diatas peneliti memfokuas penelitian ini dengan judul "Pengaruh Kepemimpinan Transformasional dan Motivasi Berprestasi Terhadap Komitmen Organisasional Studi Pada Guru di SMP Negeri 1 Selopuro Kabupaten Blitar"?

\section{Tujuan Penelitian}

Sesuai dengan latar belakang dan rumusan masalah, maka tujuan penelitian ini adalah sebagai berikut:

Menguji signifikansi pengaruh kepemimpinan transformasional terhadap komitmen organisasional pada guru di SMP Negeri 1 Selopuro Kabupaten Blitar;

1. Menguji signifikansi pengaruh motivasi berprestasi terhadap komitmen organisasional pada guru di SMP Negeri 1 Selopuro Kabupaten Blitar;

2. Menguji signifikansi pengaruh kepemimpinan transformasional dan motivasi berprestasi terhadap komitmen organisasional pada guru di SMP Negeri 1 Selopuro Kabupaten Blitar.

\section{Kerangka Konsep}

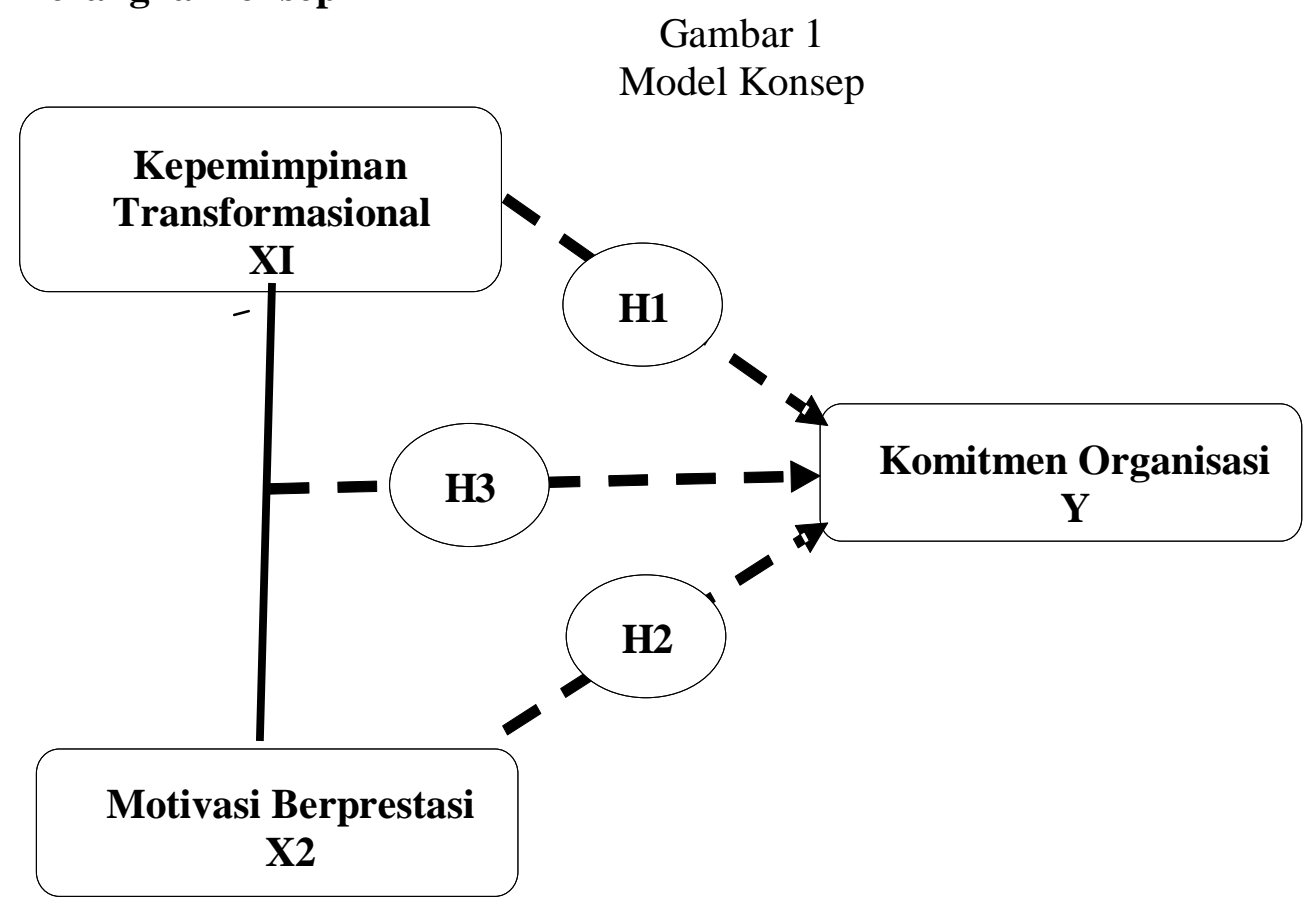




\section{Hipotesis}

Berdasarkan penelitian tersebut dapat dirumuskan hipotesis sebagai berikut:

H1 :Terdapat pengaruh signifikan dari Motivasi Berprestasi terhadap Komitmen Organisasional.

H2 :Terdapat pengaruh signifikan dari gayakepemimpinan transformasional terhadap Komitmen Organisasional

H3 :Terdapat pengaruh signifikan dari gayakepemimpinan transformasional dan Motivasi Berprestasi terhadap Komitmen Organisasional.

\section{METODE PENELITIAN \\ Jenis Penelitian}

Dilihat dari tingkat eksplanasi, penelitian ini termasuk penelitian Komparatif dengan hubungan kausal, bahwa "penelitian komparatif merupakan penelitian yang bertujuan untuk mengetahui perbandingan atau pengaruh antara dua variabel atau lebih.Sedangkan hubungan kausal adalah sebab akibat, bila $\mathrm{X}$ maka Y".(Sugiono,2013).Dilihat dri jenis data penelitian ini termasuk penelitian kuantitatif (Arikunto,2013) dan"data kuantitatif adalah data yang berbentuk angka atau data kualitatif yang diangkakan".Menurut Sugiono, (2013) maka jenis penelitian yang digunakan adalah termasuk dalam penelitian menguji hipotesis (hypothesis testing reserch).

Lokasi yang akan menjadi tempat penelitian adalah SMP Negeri 1 Selopuro Kabupaten Blitar yang berlokasi di Desa Jatitengah Selopuro Blitar, Telp. 0342.691756". Alasan pengambilan lokasi penelitian tersebut adalah data yang dibutuhkan dapat diperoleh dan data tersebut layak untuk dijadikan obyek penelitian serta sesuai dengan permasalahan yang akan diteliti mengenai komitmen guru dalam organisasi.

\section{Populasi dan Sampel}

Populasi merupakan keseluruhan obyek atau subyek yang memiliki kualitas dan karakteristik tertentu ysng ditetapkan oleh peneliti untuk dipelajari dan kemudian diatrik kesimpulannya. (Arikunto, 2013). Adapun yang menjadi "populasi dari penilitian ini adalah seluruh Guru di SMP Negeri I Selopuro Kabupaten Blitar.

Jika hanya meneliti sebagian dari populasi, maka dilakukan dengan pengambilan sampel. Menurut Arikunto (2013: 109) yang dikatakan sampel adalah sebagian obyek atau wakil dari populasi yang akan diteliti. Dinamakan penelitian sampel apabila peneliti bermaksud untuk menggeneralisasikan hasil penelitian sampel. Adapun pengambilan sampel dapat dilakukan dengan teknik sampling random, peneliti "mencampur" subjek-subjek di dalam populasi sehingga semua subjek dianggap sama, yaitu Guru SMP Negeri I Selopuro Kabupaten Blitar. Jumlah guru kesluruhan di SMP Negeri I Selopuro Kabupaten Blitar berdasarakan datan 2017 Sebanyak 39 Orang Guru tetap PNS, 4 Guru Honorer (GTT). Jumlah ini lah yang akan menjadi populasi dalam pebelitian ini sebanyak 43 orang. Dikarenakan kurang dari 100 orang maka populasi itu dibuat dipakai semua menjadi sampel penelitian. Jadi dapat disimpulkan populasi dan sampel sebanyak 43 orang dalam penelitian ini. 


\section{Variabel Penelitian}

\section{Variabel Bebas (Independent Variable)}

Adalah variabel yang menjadi sebab terjadinya perubahan pada variabel terikat (dependent). Adapun varibel bebas (independent)t dalam penelitian ini adalah Kepemimpinan Transformasional (X1), Motivasi berprestasi (X2)

\section{Variabel Terikat (Dependent Variable)}

Adalah variabel tak bebas yang dipengaruhi oleh variabel independent. Adapun yang menjadi variabel terikat (dependent) dalam penelitian ini adalah Komitmen Organisasional (Y).

\section{Definisi Konseptual}

Definisi konseptual ini menjelaskan tentang variabel penelitian yang meliputi variabel Kepemimpinan Transfomasional sebagai varibel bebas (independent), variabel Motivasi berprestasi sebagai varibel bebas (independent) dan variabel Komitmen Organisasionalsebagai variabel terikat (dependent).

\section{Definisi OperasionalVariabel}

Definisi operasional adalah suatu operasional yang ditujukan pada variabel atau dengan cara memberikan arti pada kegiatan operasional yang perlu mengukur variabel tersebut : Kepemimpinan Transformasional (X1), Motivasi Berprestasi (X2), Komitmen Organisasional (Y).

\section{Metode Analisis Regresi Berganda}

Analisis yang digunakan untuk peramalan masa yang akan datang, apabila akan diadakan perubahan pada variabel bebas. Adapun rumus Regresinya adalah:

$\mathrm{Y}=\mathrm{a}+\mathrm{b}_{1} \mathrm{X}_{1}+\mathrm{b}_{2} \mathrm{X}_{2}+e$ (Sigiyono, 2013)

Dimana:

$\mathrm{Y}=$ Variabel bebas

$\mathrm{a}=$ Bilangan konstanta

$\mathrm{b}=$ koefisien regresi

$\mathrm{x}=$ Variabel bebas

\section{PEMBAHASAN}

Hasil uji normalitas menunjukan bahwa nilai Kolmogorov-Smirnov Z padavariabel kepemimpinan transformasional (X1)sebesar 1,043; motivasi berprestasi (X2) sebesar 1,097; dan variabel komitmen organisasional (Y)sebesar 0,835 dan semua variabel tersebut mempunyai Asymp. Sig. (2-tailed) lebih besar dari 0.05 , maka dapat disimpulkan bahwa data terdistribusi dengan normal.

Hasil uji multikolinieritas menunjukkan bahwa syarat untuk lolos dalam uji multikolinieritas sudah terpenuhi oleh seluruh variabel independen yang ada, yaitu nilai tolerance yang lebih besar dari 0,1000 dan nilai VIF (Variance Inflation Factor) yang tidak lebih dari 10. Diketahui nilai VIF variabel independent sebesar 1,976. Dengan demikian dapat disimpulkan bahwa model pada penelitian ini memenuhi syarat untuk menjadi model regresi yang baik 
ksrena nilainya masih di bawah 95\% sehingga masih dapat dikatakan tidak terjadi multikolinieritas (non- multikolinieritas).

Hasil uji autokerelasi diketahui bahwa nilai DW 1,259. Selanjutnya nilai ini akan dibandingkan dengan nilai dU dan dL pada tabel Durbin Watson dengan taraf signifikansi 5\%, jumlah sampel (N) 43, dan jumlah variabel independent adalah 2, maka diperoleh nilai DW hitung sebesar dL 1,4151 dan dU 1,6091. Hipotesis tidak ada autokorelasi karena DW hitung lebih kecil dibanding dl atau 0 $<\mathrm{dw}<\mathrm{dL}$ yaitu $0<1,259<1,4151$.

Hasil Uji heteroskedastisitas menunjukkan gambar Grafik Scarterplot terlihat bahwa distribusi data tidak teratur dan tidak membentuk pola tertentu, serta titik-titik menyebar secara acak diatas maupun dibawah angka 0 pada sumbu $\mathrm{Y}$, sehingga dapat disimpulkan bahwa model pada penelitian ini memenuhi syarat untuk menjadi model yang baik karena merupakan model yang homoskedastisitas (tidak terjadi heteroskedastisitas) atau varians dan nilai residual pengamatan satu dengan pengamatan yang lain tetap.

Persamaan regresi berganda $Y=52,273-0,436 \mathrm{X} 1+0,744 \mathrm{X} 2$

Adapun interpretasi hubungan antara variabel kepemimpinan transformasional (X1), variabel motivasi berprestasi (X2) terhadap variabel komitmen organisasional $(\mathrm{Y})$ berdasarkan persamaan diatas adalah:

\section{a. $\mathbf{a}=\mathbf{5 2 , 2 7 3}$}

Jika segala sesuatu pada yang terdiri dari kepemimpinan transformasional (X1) dan motivasi berprestasi (X2) tidak terjadi multikolinearitas dianggap konstan atau tetap, maka komitmen organisasional (Y) guru di SMP Negeri 1 Selopuro Kabupaten Blitar adalah konstan atau tetap sebesar 52,273 point atau unit.

b. $b_{1}=-\mathbf{0 , 4 3 6}$

Nilai parameter atau koefisien $b_{1}$ ini menunjukkan bahwa apabila kepemimpinan transformasional (X1) meningkat, maka akan turun komitmen organisasional (Y) guru di SMP Negeri 1 Selopuro Kabupaten Blitar adalah konstan atau tetap sebesar $-0,436$ point atau unit. Demikian pula sebaliknya, apabilakepemimpinan transformasional (X1) turun, maka akan meningkat komitmen organisasional (Y) guru di SMP Negeri 1 Selopuro Kabupaten Blitar adalah konstan atau tetap sebesar $-0,436$ point atau unit.

c. $\mathbf{b}_{2}=\mathbf{0 , 7 4 4}$

Nilai parameter atau koefisien $b_{1}$ ini menunjukkan bahwa apabila kepemimpinan transformasional (X1) meningkat, maka akan meningkat komitmen organisasional (Y) guru di SMP Negeri 1 Selopuro Kabupaten Blitar adalah konstan atau tetap sebesar 0,744 point atau unit. Demikian pula sebaliknya, apabila kepemimpinan transformasional (X1) meningkat, maka akan meningkat komitmen organisasional (Y) guru di SMP Negeri 1 Selopuro Kabupaten Blitar adalah konstan atau tetap sebesar 0,744 point atau unit.

Tabel 1.

Pengujian Hipotesis Partial

\begin{tabular}{|c|c|c|c|c|c|c|c|c|c|}
\hline $\mathrm{H}$ & $\mathrm{i}$ & $\mathrm{p}$ & $\mathrm{O}$ & $\mathrm{t}$ & $\mathrm{e}$ & $\mathrm{S}$ & $\mathrm{i}$ & i $\quad 1$ & Status \\
\hline \multicolumn{8}{|c|}{ 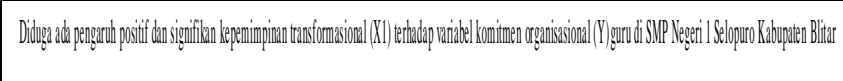 } & $\begin{array}{l}\mathrm{t}_{\text {hitung }}=-1.081 \\
\text { Sig } \mathrm{t}=0,286\end{array}$ & H1 Ditolak \\
\hline
\end{tabular}




\begin{tabular}{|c|c|c|}
\hline & $\mathrm{t}_{\text {tabel }}=2,023$ & \\
\hline 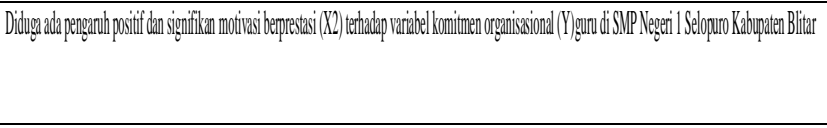 & $\begin{array}{l}\mathrm{t}_{\text {hitung }}=2.565 \\
\text { Sig } \mathrm{t}=0,014 \\
\mathrm{t}_{\text {tabel }}=2,023\end{array}$ & H2 Diterima \\
\hline
\end{tabular}

Sumber: Hasil output SPSS data primer yang diolah, 2017

Analisa data menunjukkan bahwa $\mathrm{H} 1$ ditolak. Artinya tidak terdapat pengaruh positif dan signifikan kepemimpinan transformasional (X1) terhadap komitmen organisasional (Y) guru di SMP Negeri 1 Selopuro Kabupaten Blitar. Hasil penelitian ini tidak mendukung hipotesis 1 bahwa ada pengaruh positif dan signifikan kepemimpinan transformasional terhadap komitmen organisasional (Y) pada penelitian Yuliati (2015).

Analisa data menunjukkan bahwa $\mathrm{H} 2$ diterima. Artinya terdapat pengaruh positif dan signifikanmotivasi berprestasi (X2) terhadap komitmen organisasional (Y) guru di SMP Negeri 1 Selopuro Kabupaten Blitar. Hasil penelitian ini tidak mendukung hipotesis 1 bahwa ada pengaruh positif dan signifikan kepemimpinan transformasional terhadap komitmen organisasional $(\mathrm{Y})$ pada penelitian Yuliati (2015).

Tabel 2.

Hasil Uji F

\begin{tabular}{|c|c|c|c|c|c|c|c|c|c|}
\hline $\mathrm{H}$ & $\mathrm{i}$ & $\mathrm{p}$ & o & $\mathrm{t}$ & e & $\mathrm{s}$ & $\mathrm{i}$ & $\begin{array}{llll} & \mathrm{i} & \mathrm{i} & \mathrm{a}\end{array}$ & St at u s \\
\hline \multicolumn{8}{|c|}{ 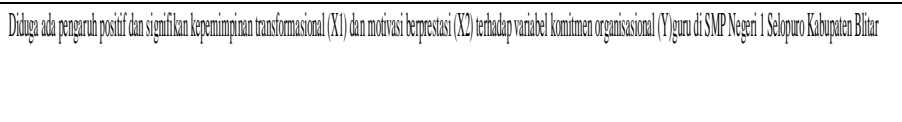 } & $\begin{array}{l}F_{\text {hitung }}=3.807 \\
\text { Sig } F=.031 \\
F_{\text {tabel }=3,23}\end{array}$ & H3 Diterima \\
\hline
\end{tabular}

Sumber: Hasil output SPSS data primer yang diolah, 2017

Analisa data menunjukkan bahwaH3 diterima. artinya kepemimpinantransformasional (X1) dan motivasi berprestasi (X2) berpengaruh sangat rendah terhadap komitmen organisasional (Y) guru di SMP Negeri 1 Selopuro Kabupaten Blitar. Hasil penelitian ini membuktikan bahwa hipotesis yang menyatakan bahwa ada pengaruh kepemimpinan transformasional (X1) dan motivasi berprestasi (X2) berpengaruh secara bersama-sama terhadap komitmen organisasional (Y) pada jurnal penelitian Yohan Mandala Wicaksono (2014) terbukti kebenarannya. Motivasi berprestasi memegang peranan kunci, sedangkan kepemimpinan transformasional sebagai variabel mediasi tidak berpengaruh nyata terhadap peningkatan komitmen organisasional guru di SMP Negeri 1 Selopuro Kabupaten Blitar. Jadi, bukan kepemimpinan transformasional kepala sekolah memunculkan perilaku komitmen organisasional guru di SMP Negeri 1 Selopuro Kabupaten Blitar, tetapi yang paling berpengaruh adalah motivasi berprestasi.

Model Summary ${ }^{\mathrm{b}}$ diketahui nilai koefisien determinasi (Adjusted $R$ Square) sebesar 0,118. Artinya kepemimpinan transformasional (X1) dan motivasi berprestasi (X2) mempengaruhi komitmen organisasional (Y) sebesar $11,8 \%$ sedang sisanya $88,2 \%$ dipengaruhi oleh variabel lain di luar model regresi ini, pengaruh variabel lain ini sering disebut sebagai error (e). Jadi dapat disimpulkan bahwa kepemimpinan transformasional (X1) dan motivasi berprestasi (X2) sangat rendah berpengaruh terhadap komitmen organisasional (Y) guru di SMP Negeri 1 Selopuro Kabupaten Blitar. 
Variabel dominan pada penelitian ini dapat dilihat dari nilai Beta pada persamaan koefisien regresi pada kolom $\mathrm{B}$, dari ketiga variabel bebas yang dominan. Nilai yang tertinggi pada koefisien Beta inilah yang merupakan variabel dominan, pada penelitian ini nilai yang tertinggi adalah motivasi berprestasi (X2) yaitu 0,523 artinya motivasi berprestasi (X2) memberikan pengaruh yang sangat besar terhadap peningkatan komitmen organisasional (Y) guru di SMP Negeri 1 Selopuro Kabupaten Blitar.

\section{Implikasi}

1. Hasil penelitian ini tidak mendukung hipotesis 1 bahwa ada pengaruh positif dan signifikan kepemimpinan transformasional terhadap komitmen organisasional (Y) pada penelitian Yuliati (2015).

Implikasi kebijakan menyatakan bahwa dengan perilaku pemimpin yang kurang mampu menumbuhkan rasa bangga dan kepercayaan bawahan, menginspirasi dan memotivasi bawahan, merangsang kreativitas dan inovasi bawahan, memperlakukan setiap bawahan secara individual serta kurang selalu melatih dan memberi pengarahan kepada bawahan, akan menumbuhkan komitmen yang kuat dari para guru terhadap organisasi mereka. Komitmen organisasional ditandai dengan keterikatan emosional dan rasa bangga terhadap organisasi, tidak memiliki keinginan untuk meninggalkan organisasi, serta memiliki kewajiban dan tanggung jawab untuk bertahan dalam organisasi. Sehingga kepemimpinan yang ada di SMP Negeri 1 Selopuro Kabupaten Blitar belum dapat menciptakan kominmet organisasi terhadap guru dan karyawan, Maka dari itu perlu adanya sigkronisasi antara kepala sekolah dan guru melalui peningkatan komunikasi organisasional..

2. Hasil penelitian ini membuktikan bahwa hipotesis yang menyatakan bahwa ada pengaruh motivasi berprestasi (X2) berpengaruh terhadap komitmen organisasional (Y) pada jurnal penelitianMarwan Petra Surbakti (2013) terbukti kebenarannya.

Implikasi kebijakan yang dapat dihubungkan dengan temuan-temuan yang dihasilkan dalam penelitian ini, Motivasi berprestasi pada guru sangatlah penting di karenakan dapat tercermin dalam implikasi kinerjanya, hal ini dapat mewujudkan citia-cita atau tujuan dari organisasi yang meliputi indikator variabel motivasi terdiri dari: Motif; Harapan; insentif.

3. Hasil penelitian ini membuktikan bahwa hipotesis yang menyatakan bahwa ada pengaruh kepemimpinan transformasional (X1) dan motivasi berprestasi (X2) berpengaruh secara bersama-sama terhadap komitmen organisasional (Y) pada jurnal penelitian Yohan Mandala Wicaksono (2014) terbukti kebenarannya.

Implikasi kebijakan yang dapat dihubungkan dengan temuan-temuan yang dihasilkan dalam penelitian ini adalah para guru pada organisasi ini bekerja selain Motivasi berprestasi memegang peranan kunci, sedangkan kepemimpinan transformasional sebagai variabel mediasi tidak berpengaruh nyata terhadap peningkatan komitmen organisasional guru di SMP Negeri 1 Selopuro Kabupaten 
Blitar. Jadi, bukan kepemimpinan transformasional kepala sekolah memunculkan perilaku komitmen organisasional guru di SMP Negeri 1 Selopuro Kabupaten Blitar, tetapi yang paling berpengaruh adalah motivasi berprestasi.

\section{PENUTUP}

\section{Kesimpulan}

Penelitian ini tentang kepemimpinan transformasional dan motivasi berprestasi terhadap komitmen organisasional Guru di SMP Negeri 1 Selopuro Kabupaten Blitar diperoleh kesimpulkan sebagai berikut:

a. Tidak terdapat pengaruh positif dan signifikan kepemimpinan transformasional terhadap komitmen organisasional guru di SMP Negeri 1 Selopuro Kabupaten Blitar;

b. Terdapat pengaruh positif dan signifikan motivasi berprestasi terhadap komitmen organisasional guru di SMP Negeri 1 Selopuro Kabupaten Blitar;

c. Terdapat pengaruh positif dan signifikan kepemimpinantransformasional dan motivasi berprestasi secara simultan terhadap komitmen

\section{Saran} organisasional guru di SMP Negeri 1 Selopuro Kabupaten Blitar.

a. Disarankan bagi peneliti selanjutnya agar dapat melakukan penelitian pada komponen lain selain masalah kepemimpinan transformasional, motivasi berprestasi terhadap komitmen organisasional guru yang telah dibahas oleh penulis atau dengan dimensi dan indikator yang berbeda sehingga pengetahuan akan ilmu manajemen sumber daya manusia untuk masyarakat akan semakin berkembang dan bermanfaat serta dapat menghasilkan ide-ide kreatif yang tentunya berguna untuk masa yang akan datang;

b. Disarankan bagi peneliti lain agar dapat melakukan penelitian lebih mendalam terhadap kombinasi dari kedua determinan mnegenai komitmen organisasional;

c. Disarankan bagi institusi agar meningkatkan komitmen organisasional guru di SMP Negeri 1 Selopuro Kabupaten Blitar, dapat memperhatikan hubungan kepemimpinantransformasional dan motivasi berprestasi sehingga capaian akhir yaitu peningkatan komitmen organisasional dapat dilaksanakan dengan baik.

\section{DAFTAR PUSTAKA}

A.S. Munandar, Bertina Sjabadhyni dan Rufus Patty Wutun. 2004. Peran BudayaOrganisasi dalam Peningkatan Unjuk Kerja Perusahaan. Depok: Penerbit PIOFakultas Psikologi UI.

Anwar Prabu Mangkunegara. 2011. Manajemen Sumber Daya Manusia. Bandung: PT. Remaja Rosdakarya.

Arikunto, Suhasimi. 2013. Prosedur Penelitian Suatu Penddekatan Prakti. Rineke Cipta, Jakarta.

Augusty, Ferdinand. 2010. Metode Penelitian Manajemen. Semarang: Badan Penerbit Universitas Diponegoro. 
Candra, Heri. 2013. Pengaruh Kepemimpinan Transformasional dan Pemeberian Insentif Terhadap Kienrja Karyawan dan Tingkat Perputaran (Studi pada PT. Honda Semoga Jaya di Samarinda - Kalimantan Timur. Tesis. Universitas Atma Jaya Yogyakarta.

Hadi, Sutrisno. 2014. Metodologi Research Jilid 3. Yogyakarta: Andi

Handoko, T. Hani, 2012. Manajemen Personalia dan Sumber Daya Manusia, Edisi kedua. Yogyakarta: BPFE.

Harold Koontz dan C.O'Donnel. 1996. Principles of Management. New York: Mc Graw-Hill Book

Hasibuan, M. 2013. Organisasi dan Motivasi: Dasar Peningkatan Produktivitas. Jakarta: Bumi Aksara.

Hasibuan, Malayu SP. 2013. Manajemen Sumber Daya Manusia. Edisi Revisi Jakarta: Bumi Aksara.

Imam Ghozali. 2009. Analisis Multivariate dengan SPSS. Semarang:BPUNDIP

Kurniasari, Luvi. 2014. Pengaruh Komitmen Organisasi dan Job Security terhadap Intensi Turnover di PT Indo C. Tesis Ilmu Manajemen, Program Pascasarjana, Universitas Airlangga. Tidak Dipublikasikan.

Laka, Mmakgomo Roseline dan Mathebula. 2013. Modelling the Relationship

Mangkunegara Anwar Prabu. 2013. Manajemen Sumber Daya Manusia Perusahaan. Cetakan Keenam, PT. Remaja Rosdakarya, Bandung.

Ordway Tead. 1985. The Art Leadership. New York: MC. Graw-Hill.

Pasolong, Harbani. 2010. Kepemimpinan Birokrasi. Bandung: Alfabeta

Rauch \& Behling. 1984. Dalam Pelatiahan Menejerial SPMK. Yogyakarta: UGM

Sugiyono. 2013. Metode Penelitian Kuantitatif dan Kualitatif. Bandung: Alfa Beta

Sunyoto, Danang, 2013. Teori, Kuesioner, dan Analisis Data Sumber Daya Manusia (Praktik Penelitian).Cetakan ke-2. Yogyakarta: CAPS.

Sutikno, Sobry. 2014. Metode \& Model-Model Pembelajaran Menjadikan ProsesPembelajaran Lebih Variatif, Aktif, Inovatif, Efektif, dan Menyenangkan. Lombok: Holistica.

Sutrisno, Edy. 2011. Manajemen Sumber Daya Manusia. Edisi 1. Cetakan Kedua. Jakarta: Prenada Media Group.

Terry, George. 2005. Dasar-Dasar Manajemen. Jakarta: PT. Bumi Aksara.

Thoha, Miftah. 2014. Perilaku Organisasi: Konsep dasar dan Aplikasi. Jakarta: PT. Raja Wali.

Veithzal, Rivai. 2014. Manajemen Sumber Daya Manusia. Raja Grafindo Persada; Jakarta.

Wijayanti, Feny Candra. 2013.PengaruhKepuasanKerjadan Komitmen OrganisasionalTerhada KeinginanUntukKeluar(Intensi Keluar) Dari Suatu Organisasi Pada Perawat di RSI Hidayatullah Yogyakarta. Dalam Jurnal Manajerial Volume 5 No. 2. Hal 1-9. 